\title{
Practical Legal Training in Legal Education: Law Students' Perceptions
}

\author{
Azni binti Mohd Dian ${ }^{1 *} \quad$ Jasmine binti Ahmad $^{2} \quad$ Siti Nuramani binti Abdul Manab ${ }^{1}$ \\ 1.Faculty of Law, Universiti Teknologi MARA, 40450 Shah Alam, Selangor Darul Ehsan, Malaysia \\ 2.Faculty of Administrative Science and Policy Studies, Universiti Teknologi MARA, 40450 Shah Alam, \\ Selangor Darul Ehsan, Malaysia
}

This research paper is an excerpt from an ongoing research project entitled Teaching and Learning in Legal Education: A Paradigm Shift from Theory to Legal Practical Training (600-IRMI/DANA 5/3/ARAS (0100/2016) generously funded and managed by the Institute of Research Management \& Innovation (IRMI), Universiti Teknologi MARA (UiTM). We would like to express our gratitude to those who, directly or indirectly, involved throughout the initial findings stage.

\section{Abstract}

Many legal practitioners believed that law schools have two educational objectives: to prepare their students for admission to the bar and to equip students with effective, ethical, and responsible participation as members of the legal profession. Recently, there has been much concern of members of the legal profession over some law schools producing students who lacked with day-to-day lawyering skills. They viewed that the law schools have placed their focus more on the solid grounding in the traditional areas of legal theory and lack of the practical legal training. As a result, law graduates are primarily unprepared for the necessary lawyering skills to face the real life as advocates and solicitors. The objectives of this research were to determine whether the law schools have adequately prepared their students with sufficient practical legal skills, particularly the lawyering skills and whether the legal educators' professional legal background plays significant roles in the practical legal education. Applying a quantitative method, this research seeks the perception of the final year law students and law graduates who are currently working in the legal profession to meet its objectives. The findings revealed that while the practical legal training, particularly the lawyering skills are deemed to be essential tools to meet the educational objectives, these skills would only be effective and beneficial to the students if they are delivered by experienced legal educators with their qualified professional legal background. If these aspects are given due attention, the law schools should get a credit for applying the efficient practical legal training approach and evidently prepare their graduates to meet the demand and expectation of "the real world" of law practice.

Keywords: teaching, practical legal training, professional background, legal educators

DOI: $10.7176 / \mathrm{JEP} / 11-5-10$

Publication date: February $29^{\text {th }} 2020$

\section{Introduction}

There are views that law schools have the duty to produce not only law graduates but also quality lawyers with the ability to "hit the ground running" to practice law upon graduation (Neil, 2013). Professional legal skills demanded by the legal profession today are recognized as fundamental criteria in the practical legal training (Paul (2014). In Malaysia, the Chief Justice has taken young lawyers to task for their lack of advocacy skills (The Star, 16 July 2016). It appears that the traditional legal education fails to develop the practical, day-to-day lawyering skills needed as an entry-level lawyer, such as the trial and advocacy, clients and witness interviewing, client counselling, negotiating, mediating, drafting etc. (Daily Express, 1 Jan 2017).

In attending to the issue on how well law schools prepared law graduates for the actual practice of law, the American Bar Association has conducted a survey which revealed that legal practice skills or lawyering skills could be learned in law schools (MacCrate Report, 1992). In Malaysia, the Faculty of Law ('Faculty'), Universiti Teknologi MARA (UiTM), Shah Alam is the only public university that executes a one-year professional legal training for the students as the preparation to practice law after their graduation. However, there is no research being done to measure on how effective the Faculty practical legal training courses have prepared the law graduates before they join the legal profession.

Borrowing the fundamental legal practice skills in the MacCrate Report, 1992 this research seeks to analyse the perceptions of the UiTM law students on whether they are satisfied with the lawyering skills exposed and trained by the legal educators in the LL.B (Hons) programme. Another aspect that has been examined is whether the professional legal background of the legal educators plays significant roles in effective teaching and learning in the programme. To achieve the objective of this research, a survey was conducted on forty (40) students of the final semester of the fourth-year programme in UiTM and seven (7) UiTM law graduates who are currently working in various legal fraternities. 


\section{Literature Review}

In many countries, including Malaysia, the principal law degree is an undergraduate degree, usually known as a Bachelor of Laws (LLB). To become lawyers, graduates of such a program must pass the country's equivalent of a bar exam, namely a test that qualifies the graduate to practice in a given jurisdiction. However, this is not a requirement in Malaysia. After four years of academic studies, a law graduate in Malaysia who intends to be called to the bar as an advocate and solicitor needs to undergo a nine-month of vocational training called chambering or pupillage system. Even though under this system, the pupil is placed under the supervision of a senior lawyer of a minimum of seven years in legal practice, it has no external evaluation of whether pupils are sufficiently trained with a core set of skills necessary for them to be an advocate and solicitor. The system merely assumes that after the chambering period, a pupil has gained all the necessary skills to be admitted as an advocate and solicitor of Malaysia (Lee Shih, 2006). There is no form of Code of Conduct as guidance for pupilmasters or law firms to adhere to. Unlike Canada, a master taking on a pupil is required to submit an education plan that describes the anticipated pupilage experience to be acquired by the pupil. Thus, there are calls from the legal and judicial services that the law schools are responsible to equip their students with practice-orientated training in legal education. The present structure of the curriculum needs to divert its focus from the traditional areas of substantive laws on the development of professional legal skills.

\subsection{Professional Legal Training in Faculty of Law, UiTM and MQA Recognition}

The Faculty of Law, UiTM began as a center offering British external programs, namely the LL.B (LondonExternal). In 1978, UiTM introduced the Diploma in Law (DIL) programme which is equivalent to the LL.B programme offered in British Universities. It is a three-year academic programme based on the structure of British Universities undergraduate law programmes. In 1982, a one-year Advanced Diploma in Law (ADIL) programme for graduates of the DIL programme was offered. The ADIL programme is equivalent to an LL.B (Hons) degree and recognised for legal practice. In 2002, the LL.B program had been replaced with a three year Bachelor of Legal Studies (BLS Hons) but was then revised and combined with the one-year LL.B (Hons) that gave birth to the current four-year LL.B (Hons) programme.

The delivery of the curriculum for the fourth year programme (final one year) adopts the method and strategy of simulated or experiential learning where students are assigned to their respective legal firms throughout that one year. At this level, the students are exposed to all the lawyering skills has been practiced and applied in the real legal professional atmosphere. All these exposures undoubtedly demand expertise and training from experienced and qualified legal educators to unfold the day-to-day work of practicing lawyers. Many of the legal educators' qualification for this programme comprised of not only lecturers of the tertiary qualification in law, but also former practicing lawyers. Some of them are part-time advocates and solicitors, forensic experts and magistrates of at least five-year experienced in their respective profession.

The quality and standards of LL.B (Hons) programme has been accredited by the Malaysian Qualifications Agency, (MQA), a statutory body which is responsible in overseeing quality assurance of Malaysian higher education (MQA-02 / IQA-02 Report for Programme LW224 Full Accreditation). The recommended qualities established under the MQA framework are indeed in tandem with the visions, missions, and goals of UiTM in general and the Faculty in particular, i.e. to provide students with dynamic involvement in all professional fields of world-class through professional programmes. Besides, it is one of the missions of the Faculty to ensure that the academic staff is qualified, experienced and of high calibre.

\subsection{Lawyering Skills and Theoretical Consideration}

One of the objectives of legal education is to prepare students with the lawyering skills and competencies. It is a significant concern of the legal fraternity on what the students can do with what the students have learned during their legal studies (Baird, 1978). Some views demonstrate that the study of law is the study of lawyering (Ann, 2011; Russell \& Sammons, 1980; Benthall-Nietzel, 1975). The MacCrate Report 1992 has identified several core lawyering skills to prepare students to practice effectively in the legal profession: 1. Problem Solving Skill; 2. Legal Analysis and Reasoning; 3. Legal Research; 4. Factual Investigation; 5. Communication; 6. Counselling; 7. Negotiation; 8. Litigation and 9. Drafting of Legal Documents. In the MacCrate Report 1992, it reveals that most of the attorneys perceived that the lawyering skills defined by MacCrate are all significant and relevant to legal practice and they could be taught successfully in law schools (MacCrate Report 1992, Chapter 7 page 236). It appears that the fundamental lawyering skills in the MacCrate Report 1992 correlate and correspond to the vision, mission, and goals of UiTM and the Faculty as demonstrated in the MQA documents.

In UiTM, the first 3 years of the LL.B (Hons) program, educate the students to non-experiential courses that present and exposed students to the knowledge and understanding of the substantive and procedural laws, legal analysis and reasoning, legal research, problem-solving, and written and oral communication in the legal context. In addition, students need to know how to exercise proper professional and ethical responsibilities to clients and the legal system. During the final one-year professional programme, students are exposed to practical lawyering 
skills, among others are the Non-Contentious Legal Matters (Conveyancing \& Probate), Criminal Trial and Advocacy, Civil Trial and Advocacy, Magisterial Skills, and Forensic Science. Every lawyering activity involves at least some aspects of oral or written competency, professional responsibility and practice management competencies.

\subsection{Legal Practice Background of Legal Educators}

Many types of research also indicate that the quality of teachers and their teaching are the most important factors for student outcomes and career development (Thompson, 2009; Christensen \& Leah, 2012). This includes the qualification background of the legal educators teaching the practical legal training (David, N.Y.Times, 19 November 2011). One of the law schools in Australia, for example, the College of Law, Sydney develops and offers the Practical Legal Training (PLT) Program that provides post-graduate training particularly the lawyering skills. In engaging legal educators to teach the PLT program, the College requires the applicants to acquire not only the tertiary qualification in law but also to have at least 5 years' post-admission experience as a legal practitioner (College of Law website). It is also the desirable qualifications of the College that the legal educators have the thorough knowledge of legal practice in property, commercial or litigation areas. The Law School of the University of Wisconsin is another example that offers comprehensive legal training courses as part of the law school curriculum since 1948 and taught by qualified legal practitioners (University of Wisconsin website).

The above requirements demonstrate that the educators' professional legal background is crucial to assist law schools to provide quality academic studies as well as furnishing the students with all relevant insights into what it is like to work in a real legal practice environment. However, the question of what constitutes an integrated model of lawyering skills and competencies in the legal education network has not been seriously considered by many other law schools in Malaysia.

\section{Methodology}

This study adopts a quantitative and qualitative approach. The quantitative approach acquired the data through a questionnaire to forty (40) law students who are currently studying in the final semester of the LL.B (Hons) program at the Faculty of Law, Universiti Teknologi MARA (UiTM). It focuses on the level of satisfaction on the lawyering skills taught by the faculty. The perception of these respondents is crucial in order to determine to what extent the Faculty of Law, UiTM adequately provides the practical legal training, particularly the aspect of lawyering skills, to prepare their students to practice law upon graduation. The questionnaires were distributed during class and a self-report using 5-point Likert rating scales was prepared in this research.

\section{Result and Discussion}

\subsection{Lawyering Skills and Practical Legal Training}

Table 1. Result of the questionnaires

\begin{tabular}{|c|c|c|c|c|c|c|}
\hline & \multirow[t]{2}{*}{$\begin{array}{l}\text { Lawyering Skills Criteria } \\
\text { Measured on the scale of }\end{array}$} & \multicolumn{5}{|c|}{$\begin{array}{l}\text { Scale } \\
1 \text { (Very Dissatisfied) to } 5 \text { (Very Satisfied) }\end{array}$} \\
\hline & & 1 & 2 & 3 & 4 & 5 \\
\hline a. & $\begin{array}{l}\text { Problem solving Skill - Able to identify and diagnose the } \\
\text { problem, developing Plan of Action and Implementing the } \\
\text { Plan }\end{array}$ & 0 & $\begin{array}{l}2 \\
(5 \%)\end{array}$ & $\begin{array}{l}15 \\
(37.5 \%)\end{array}$ & $\begin{array}{l}17 \\
(42.5 \%)\end{array}$ & $\begin{array}{l}6 \\
(15 \%)\end{array}$ \\
\hline b. & $\begin{array}{l}\text { Legal Analysis and Reasoning Skill - Able to identify } \\
\text { and formulate legal issues, evaluate legal theory and } \\
\text { synthesizing legal argument. }\end{array}$ & 0 & $\begin{array}{l}1 \\
(2.5 \%)\end{array}$ & $\begin{array}{l}13 \\
(32.5 \%)\end{array}$ & $\begin{array}{l}21 \\
(52.5 \%)\end{array}$ & $\begin{array}{l}5 \\
(12.5 \%)\end{array}$ \\
\hline c. & $\begin{array}{l}\text { Legal Research Skill - Able to identify legal issues, have } \\
\text { knowledge on nature of legal rules and implement an } \\
\text { effective research design. }\end{array}$ & 0 & $\begin{array}{l}4 \\
(10 \%)\end{array}$ & $\begin{array}{l}15 \\
(37.5 \%)\end{array}$ & $\begin{array}{l}14 \\
(35 \%)\end{array}$ & $\begin{array}{l}7 \\
(17.5 \%)\end{array}$ \\
\hline d. & $\begin{array}{l}\text { Factual Investigation Skill }- \text { Able to plan factual } \\
\text { investigation, implement investigative strategy and } \\
\text { evaluate information gathered. }\end{array}$ & $\begin{array}{l}1 \\
(2.5 \%)\end{array}$ & 0 & $\begin{array}{l}20 \\
(50 \%)\end{array}$ & $\begin{array}{l}16 \\
(40 \%)\end{array}$ & $\begin{array}{l}3 \\
(7.5 \%)\end{array}$ \\
\hline e. & $\begin{array}{l}\text { Communication Skill - Able to orally or in writing, assess } \\
\text { perspective of the recipient of the communication, use } \\
\text { effective method of communication. }\end{array}$ & $\begin{array}{l}1 \\
(2.5 \%)\end{array}$ & $\begin{array}{l}1 \\
(2.5 \%)\end{array}$ & $\begin{array}{l}8 \\
(20 \%)\end{array}$ & $\begin{array}{l}23 \\
(57.5 \%)\end{array}$ & $\begin{array}{l}7 \\
(17.5 \%)\end{array}$ \\
\hline
\end{tabular}




\begin{tabular}{|c|c|c|c|c|c|c|}
\hline & \multirow[t]{2}{*}{$\begin{array}{l}\text { Lawyering Skills Criteria } \\
\text { Measured on the scale of }\end{array}$} & \multicolumn{5}{|c|}{$\begin{array}{l}\text { Scale } \\
1 \text { (Very Dissatisfied) to } 5 \text { (Very Satisfied) }\end{array}$} \\
\hline & & 1 & 2 & 3 & 4 & 5 \\
\hline f. & $\begin{array}{l}\text { Counseling Skill }- \text { Able to establish the counseling } \\
\text { relationship that respects nature and bounds of lawyer's } \\
\text { role, gather information, counseling client, analyzing and } \\
\text { implementing decision to be made. }\end{array}$ & 0 & $\begin{array}{l}2 \\
(5 \%)\end{array}$ & $\begin{array}{l}16 \\
(40 \%)\end{array}$ & $\begin{array}{l}18 \\
(45 \%)\end{array}$ & $\begin{array}{l}4 \\
(10 \%)\end{array}$ \\
\hline g. & $\begin{array}{l}\text { Negotiation Skill }- \text { Able to prepare and conduct } \\
\text { negotiation, counseling client about terms received from } \\
\text { the other party and implement client's decision. }\end{array}$ & 1 & $\begin{array}{l}2 \\
(5 \%)\end{array}$ & $\begin{array}{l}12 \\
(30 \%)\end{array}$ & $\begin{array}{l}22 \\
(55 \%)\end{array}$ & $\begin{array}{l}3 \\
(7.5 \%)\end{array}$ \\
\hline h. & $\begin{array}{l}\text { Litigation Skill - Able to litigate and learn advocacy skill } \\
\text { at the Trial-Court level, Appellate level. }\end{array}$ & $\begin{array}{l}1 \\
(2.5 \%)\end{array}$ & $\begin{array}{l}1 \\
(2.5 \%)\end{array}$ & $\begin{array}{l}14 \\
(35 \%)\end{array}$ & $\begin{array}{l}20 \\
(50 \%)\end{array}$ & $\begin{array}{l}4 \\
(10 \%)\end{array}$ \\
\hline i. & $\begin{array}{l}\text { Drafting Skill - Able to analyze problem, research the } \\
\text { identified issues, identify applicable law and prepare a } \\
\text { written document. }\end{array}$ & 0 & $\begin{array}{l}2 \\
(5 \%)\end{array}$ & $\begin{array}{l}19 \\
(47.5 \%)\end{array}$ & $\begin{array}{l}15 \\
(37.5 \%)\end{array}$ & $\begin{array}{l}4 \\
(10 \%)\end{array}$ \\
\hline
\end{tabular}

The result of the research indicates the lawyering skills among the final semester students. A skill was considered adequately received if it scored 5 which reflects "Very Satisfied". As Table 1 shows, among the lawyering skills taught in the LL. B programme, the highest level of satisfaction scored by students is the Communication Skill (57\%), followed by Negotiation Skill (55\%), and Legal Analysis and Reasoning Skill $(52.5 \%)$. If the results of the survey are evaluated according to the percentage rate of $85 \%$ and above is for excellent, $75 \%-84 \%$ as good, and $50 \%-74 \%$ as average, this survey reveals that the students' level of satisfaction on the overall lawyering skills achievement is perceived as barely above the average level which could not be proud of.

Another two skills that obtained an average result, i.e. exactly 50\% are Factual Investigation Skill and Litigation Skill. For other professional legal skills, the results are below $50 \%$ which reflect the dissatisfaction of students in the learning process; Drafting Skill (47.5\%), Counselling Skill (45\%), Problem-solving Skill (42.5\%) and Legal Research Skill (37.5\%). From the above results, the dissatisfaction of students in the lawyering skills which obtained less than $50 \%$, may give some indications that the faculty has not adequately prepared the students with the necessary lawyering skills upon graduation.

The findings indicate that even the highest level of satisfaction rated by the students that is for Communication Skill is only 57\%, a figure which is far from good while the lowest level of satisfaction, $37.5 \%$ reflects the students' dissatisfaction on the Legal Research Skill. Legal Research Skill is crucial for students to identify legal issues and have knowledge of the nature of the legal rules in preparing their cases. The result may also indicate that lack of the above lawyering skills may affect the preparedness of students, in terms of abilities and competencies, to join legal practice upon graduation.

\subsection{Professional Legal Background of Legal Educators}

The qualitative approach analyses the interview responses of former UiTM law graduates who are now working in the legal profession as advocates and solicitors (2), lecturers of the Faculty (3) and court officials (2). Through interview sessions, the respondents were asked several general questions whether the professional legal background of the legal educators provides any significant impact on the teaching and learning process of the LL.B (Hons) programme. In their response, all seven respondents were of the view that the experienced legal educators have an added value to share their experiential background with the students efficiently.

When asked whether the legal practice skills could be learned in law schools, all seven respondents agreed that the legal skills could be acquired at the faculty level. However, many believed that the lawyering skills courses could be effectively delivered by legal practitioners or educators who have had such legal practice experience compared to non-practitioners, which eighty per cent (80\%) supported this view. They believed that the experienced educators could efficiently share hands-on in-formation and training with the students which are not available in textbooks. As a result, $80 \%$ of the respondents hold the idea that lack of legal practice experience of the educators has an adverse effect on the quality of teaching and learning process / practical legal training in the LL.B (Hons) programme.

On the other hand, even though experienced educators are deemed beneficial to the learning process development, $20 \%$ of the respondents claimed that the experiences to be shared by the practitioners are distorted 
with their lack of delivery skills to create explicit connections between teaching and their own experiences. It may be due to no specific training on lecturing skills or basic teaching methodology required, unlike school teachers. The same reason applies to the part-time advocates and solicitors engaged by the Faculty, they may be good in defending their clients in court but not in their lecturing skills. One of the challenges raised by the respondents (lecturers of the Faculty) experiencing a co-teaching with part-time legal practitioners is that even though the experiential background of the educators is beneficial to the students, there are also situations where the part-time lawyers were not prepared to class due to their busy schedule.

Their comment made was "... some practitioners will only discuss a limited number of cases which they had personally experienced in their practice and applied the same cases in many other topics throughout the semester". Hence, the respondents were of the view that it may weaken the stage of students' preparedness to embark into legal practice upon graduation. The interview result also demonstrates that even though the Faculty curriculum structure is comprehensively designed to equip students with the ability to apply their theoretical aspects of the law to the practical legal setting, the result seems disrupted by lack of professional qualification factor.

\section{Conclusion}

The results reveal that while the Faculty of Law, UiTM has successfully formulated a holistic curriculum for lawyering skills in the LL.B (Hons) professional programme, it also has the duty to ensure that the courses are efficiently delivered and exposed to the students by the legal educators. In the survey and interviews conducted, the students perceived that the lawyering skills received during their final year programme are at the average stage which answered the objective of the survey whether the Faculty has adequately prepared the students to face the real-life as advocates and solicitors. The response from UiTM former law students agreed that the professional legal background of educators is significant for effective teaching and learning processes. Likewise, the views of the law lecturers of the Faculty that lack of delivery and teaching skills of the part-time lawyers needs to be seriously addressed as the legal experience and specialized knowledge of these lawyers could assist the Faculty to provide intensive academic preparation for law students. If these aspects are efficiently attended to by the Faculty, indisputably the Faculty could produce competitive, conscientious, and confident students with the ability to "hit the ground running" to practice law which is in line with the visions, missions, and goals of UiTM and MQA.

\section{References}

Advertisement for Academic and Law Programmes. $\quad$ Retrieved from https://law.wisc.edu/academics/lawskills/gpcourses.html.

Advertisement for legal educators posted by the College of Law Australia. Retrieved from https://www.collaw.edu.au/-/media/COL/AU_Files/HR.../Lecturer_PD_May2017.pdf.

Cavazos. A.M (2011). Demands of the Marketplace Require Practical Skills: A Necessity for Emerging Practitioners, and Its Clinical Impact on Society_A Paradigm for Change, 37 J. LEGIS. 1, 6.

Baird. L.L. (1978). A Survey of the Relevance of Legal Training to Law School Graduates, Journal of Legal Education Vol. 29 No. 3. 264-294.

The Star (2016). We need better advocacy skills in young lawyers. The Star. Retrieved from https://www.thestar.com.my/news/nation/2016/07/16/chief-justice-we-need-better-advocacy-skills-inyoung-lawyers/\#xHV72OJCj48IsC9h.99.

Christensen, M. (2012) " e Power of Skills: An Empirical Study of Lawyering Skills Grades as the Strongest Predictor of Law School Success (Or in Other Words, It's Time for Legal Education To Get Serious About Integrating Skills Training throughout the Law School Curriculum If We Care About How Our Students Learn)," St. John's Law Review: Vol. 83: Iss. 3, Article 2. Available at: h p://scholarship.law.stjohns.edu/lawreview/vol83/iss3/2.

Daily Express. (2017). They don't deserve to be lawyers. Daily Express. Retrieved from http://www.dailyexpress.com.my/read.cfm?NewsID=2371.

Segal. D (2011, Nov. 20). What They Don't Teach Law Students: Lawyering. New York Times. Retrieved from https://www.nytimes.com/2011/11/20/business/after-law-school-associates-learn-to-be-lawyers.html.

Lee Shih. (2006). The Present Pupillage System - Are Pupils Being Trained Adequately? Retrieved from http://www.malaysianbar.org.my/legal_profession/the_present_pupillage_system_are_pupils_being_trained adequately_html.

MacCrate Report. (1992). Legal Education and Professional Development - An Educational Continuum. Report of The Task Force on Law Schools and the Profession: Narrowing the Gap. American Bar Association Section of Legal Education and Admissions to the Bar, July 1992. Available @ https://www.americanbar.org/content/dam/aba/publications/misc/legal_education/2013_legal_education_an d_professional_development_maccrate_report).authcheckdam.pdf. 
Dilloff N.J (2013). Law School Training: Bridging the Gap between Legal Education and the Practice of Law, 24 STAN. L. \& POL'Y REv. 425, 427-28.

Radvany. P (2014). Preparing Law Students to Become Litigators in the New Legal Landscape, 33 Rev. of Litig. 881. Available at: http://ir.lawnet.fordham.edu/faculty_scholarship/594

Thompson, S.E (2009) "Developing a Comprehensive Approach to Teaching Lawyering Skills: A Response to the MacCrate Report Fifteen Years Later". Faculty Publications and Presentations. Paper 49. http://digitalcommons.liberty.edu/lusol_fac_pubs/49. 